\title{
Adsorption and Post Adsorption Behavior of Schwertmannite with Various Oxyanions
}

\author{
Khandala Khamphila1, Ritsu Kodama1, Tsutomu Sato ${ }^{2}$, Tsubasa Otake ${ }^{2}$ \\ ${ }^{1}$ Graduate School of Engineering, Hokkaido University, Hokkaido, Japan \\ ${ }^{2}$ Faculty of Engineering, Hokkaido University, Hokkaido, Japan \\ Email: khankhamphila@yahoo.com
}

How to cite this paper: Khamphila, K., Kodama, R., Sato, T. and Otake, T. (2017) Adsorption and Post Adsorption Behavior of Schwertmannite with Various Oxyanions. Journal of Minerals and Materials Characterization and Engineering, 5, 90-106. https://doi.org/10.4236/jmmce.2017.52008

Received: February 27, 2017

Accepted: March 28, 2017

Published: March 31, 2017

Copyright $\odot 2017$ by authors and Scientific Research Publishing Inc. This work is licensed under the Creative Commons Attribution International License (CC BY 4.0).

http://creativecommons.org/licenses/by/4.0/

(c) $\underset{\mathrm{EY}}{0}$ Open Access

\begin{abstract}
The adsorption and post adsorption behavior of schwertmannite with various oxyanions were investigated for clean-up contaminated water with hazardous oxyanions and safe disposal of spent schwertmannite. The result of adsorption experiments showed that the maximum capacities of oxyanions adsorption onto schwertmannite are $1.023,0.934,0.723$ and $0.313 \mathrm{mmol} / \mathrm{g}$ for arsenate, phosphate, chromate and selenate, respectively. Based on the differences in the adsorption capacities, the selectivity of oxyanion adsorption on schwertmannite decreases as the order: arsenate $\geq$ phosphate $>$ chromate $>>$ selenate. Change in the Zeta potential after adsorption by arsenate, phosphate and chromate were very different from those after adsorption by selenate and of the original schwertmannite. This difference implies that the adsorption mechanism on schwertmannite with arsenate, phosphate and chromate is different from that with selenate and sulfate. Arsenate, phosphate, and chromate ions form inner-sphere complexes with the surface of schwertmannite, while selenate and sulfate ions form outer-sphere complexes with the surface of schwertmannite. Based on a comparison with anion adsorption, strong base anions form inner-sphere complexes, which induce a strong adsorption with schwertmannite as well as it is conducive to high adsorption capacity. From the results of aging experiments, schwertmannite with sulfate and selenate changed to a more stable phase, goethite, in a short time, whereas there is no change in the XRD patterns of schwertmannite with arsenate and phosphate after 30 days. The stability of schwertmannite after the adsorption increased in the following order: sulfate $\cong$ selenate $\ll$ chromate $<$ phosphate $\cong$ arsenate. The solubility of schwertmannite with different oxyanions was calculated according to solid solution theory. The solubility of schwertmannite decreased after adsorption of oxyanions with high selectivity. It is concluded that oxyanions with high selectivity can stabilize schwertmannite by decreasing the solubility of the schwertmannite after adsorption of the oxyanions.
\end{abstract}




\section{Keywords}

Adsorption, Oxyanions, Schwertmannite and Solid Solution

\section{Introduction}

Water contamination is one of the serious problems worldwide. The source of the contamination is both from anthropogenic as well as from natural sources. For example, the source of arsenic in contaminated water may be from active or abandoned mines, and also mineral processing and sediments [1] [2] [3] [4] [5]. To treat toxic elements such as arsenic, there are numerous established processes such as coagulation/co-precipitation, adsorption, and ion-exchange etc. [6] [7] [8]. Adsorption is an example of simple easily applied techniques. Adsorption has been reported in removal of hazardous cations using activated carbon, zeolites, and clays [9] [10]. However, the removal of toxic oxyanions is more difficult than that of removing cations because natural waters contain anions with similar structures, including nitrate, sulfate, and phosphate often coexisting in high concentrations. However, iron oxides and hydroxides are excellent scavengers both for hazardous cations and also hazardous oxyanions. In iron oxides and hydroxides, there are several mineral species such as goethite, hematite, and ferrihydrite etc. Schwertmannite is a meta-stable iron oxy- and hydroxy-sulfate found in acidic iron- and sulfate-rich environments such as sulfide metal mines [11] [12] [13] [14]. Schwertmannite is well known to play an important role in the removal toxic elements from the acid mine drainage [15] [16] [17] and in natural attenuation processes of hazardous elements in acid mine water [18].

As mentioned above, schwertmannite is a meta-stable phase and easily transforms to goethite in pure water, while it is also an excellent adsorbent. Both the adsorption capacity and the stability of adsorbents need to pay attention safety at the sites where adsorbents are deposited. However, it is also well known that the stability of schwertmannite is changed and stabilized after arsenate adsorption [19], but the adsorption and post-adsorption behavior of schwertmannite with other kinds of oxyanions have not been fully or systematically investigated. With this background, the adsorption properties of oxyanions including arsenate, phosphate, chromate, and selenate of schwertmannite were investigated. The stability of schwertmannite after adsorption of the above oxyanions was compared to gain a better understanding of the post-adsorption behavior of schwertmannite with the different oxyanions.

\section{Material and Methods}

\subsection{Preparation of Schwertmannite}

Schwertmannite was prepared by the method previously reported by Bigham et al. [13]. Mixing solution prepared by $0.04 \mathrm{M} \mathrm{Na}_{2} \mathrm{SO}_{4}$ solution and $0.04 \mathrm{M}$ $\mathrm{Fe}\left(\mathrm{NO}_{3}\right)_{3} \cdot 9 \mathrm{H}_{2} \mathrm{O}$ solution was held at $60^{\circ} \mathrm{C}$ for 12 minutes, then cooled and di- 
alyzed for 30 days, deionized water used for the dialyzing was changed every day. The produced suspension was filtered through a $0.2 \mu \mathrm{m}$ cellulose membrane then immediately freeze-dried to prevent transformation to another phases. To evaluate the chemical composition of the schwertmannite, the product was dissolved by $6 \mathrm{M} \mathrm{HCl}$ solution, then the Fe contents in the solution were measured using inductively coupled plasma atomic emission spectroscopy (ICPE-9000, ICP-AES). In addition, the product was also dissolved by $0.01 \mathrm{NaOH}$ solution, and the $\mathrm{SO}_{4}{ }^{2-}$ in the solution was measured using ion chromatography (Metrohm 861 Advanced Compact, IC). The procedures employed in this study are similar to those previously reported [19]. As a result, the chemical formula of the synthetic schwertmannite was determined as $\mathrm{Fe}_{8} \mathrm{O}_{8}(\mathrm{OH})_{4.88}\left(\mathrm{SO}_{4}\right)_{1.56}$. Further, $X$-ray diffraction (XRD) analyses were conducted to identify the synthesized phases by Rigaku $X$-Ray diffractometer with $\mathrm{CuK} \alpha$ radiation $(40 \mathrm{kV}$ and $40 \mathrm{~mA})$. From the $\mathrm{XRD}$ analyses, the synthesized products were identified as a schwertmannite because the XRD pattern was identical to that of the previously reported schwertmannite by Bigham et al. [11].

\subsection{Adsorption Experiments}

All adsorption experiments were conducted at a constant ionic strength $(\mathrm{I}=$ $0.01 \mathrm{M}, \mathrm{NaNO}_{3}$ ) by using a $50 \mathrm{ml}$ centrifuge tube adding $40 \mathrm{ml}$ solution of $\mathrm{Na}_{2} \mathrm{HPO}_{4}, \mathrm{Na}_{2} \mathrm{HAsO}_{4}, \mathrm{Na}_{2} \mathrm{CrO}_{4}$, and $\mathrm{Na}_{2} \mathrm{SeO}_{4}$ with concentrations from 0 to 2 $\mathrm{mM}$ and $40 \mathrm{mg}$ of the synthetic schwertmannite. The $\mathrm{pH}$ of the adsorption media was adjusted to $7.00 \pm 0.28$ by $0.1 \mathrm{M} \mathrm{NaOH}$ solution. The samples were placed in a reciprocal shaker at $25^{\circ} \mathrm{C}, 100 \mathrm{rpm}$ for 24 hours. The filtered solids were freeze-dried for measurements of Zeta potential (Malvern Zetasizer Nano series Nano-ZS90 instrument) and liquid samples were used for the inductively coupled plasma atomic emission spectroscopy, (ICPE-9000, ICP-AES) and ion chromatography (Metrohm 861 Advanced Compact IC instrument) to determine the concentration of elements after the adsorption. The released $\mathrm{SO}_{4}^{2-}$ and $\mathrm{Fe}$ in the equilibrium solutions were also determined.

The amout of anions adsorbedwere calculated by the difference between the initial concentration and concentration in the solution after adsorption as shown in the equation reported previously [20].

\subsection{Aging Experiments}

Dried solid schwertmannite was added to the solutions of the anions, for the adsorption process, the $\mathrm{pH}$ was adjusted by $0.1 \mathrm{M} \mathrm{NaOH}$ and $0.1 \mathrm{HNO}_{3}$ to $7.00 \pm$ 0.12 and $30-35 \mathrm{mg} / \mathrm{g}$ of the solid phase of anions of arsenate, phosphate, chromate or selenate were adsorbed on the schwertmannite, separately. The solids after the adsorption were mounted and dried on silica glass. The glasses with the mounted solid samples were kept in boxes with wet cotton at $60^{\circ} \mathrm{C}$ to accelerate alterations in a moisture condition. At the different aging times, the samples were analyzed by XRD to determine the extent of the phase transformation. 


\section{Results}

\subsection{Oxyanion Adsorption Experiments}

As shown in Figure 1, the amounts of adsorbed oxyanions increased with increasing initial concentration of anions. Arsenic ion adsorbed on schwertmannite with the highest adsorption capacity, while only small amount of selenate adsorbed on schwertmannite. The maximum adsorbed anion contents were $1.023,0.934,0.723$ and $0.313 \mathrm{mmol} / \mathrm{g}$ for arsenate, phosphate, chromate, and selenate, respectively. From the differences in the capacity, the selectivity of oxyanion adsorption on schwertmannite decreases as the order: arsenate $\geq$ phosphate $>$ chromate $\gg$ selenate.

The $\mathrm{pHs}$ of the initial solution adjusted to neutral then decreased to 3.5-4.5 after adsorption (Figure 2).

This decrease would be due to release of protons from schwertmannite during the adsorption. Further, the $\mathrm{SO}_{4}^{2-}$ concentration in the reaction solutions was determined after the adsorption because $\mathrm{SO}_{4}^{2-}$ originally adsorbed on schwertmannite. The $\mathrm{SO}_{4}^{2-}$ concentration in the reaction solution initially $0.123 \pm 0.002 \mathrm{mmol} / \mathrm{g}$ without adsorption of any other oxyanions, which is a value similar to that in previously work [21]. During the adsorption process, the released $\mathrm{SO}_{4}^{2-}$ ion concentration in the solution increased with increasing initial concentration of anions in the solution (Figure 3(a)).

However, the increasing ratios were different among the anions in the following order: arsenate $\geq$ phosphate $>$ chromate $\gg$ selenite. The released Fe concentration in the solution decreased with increasing initial concentration of

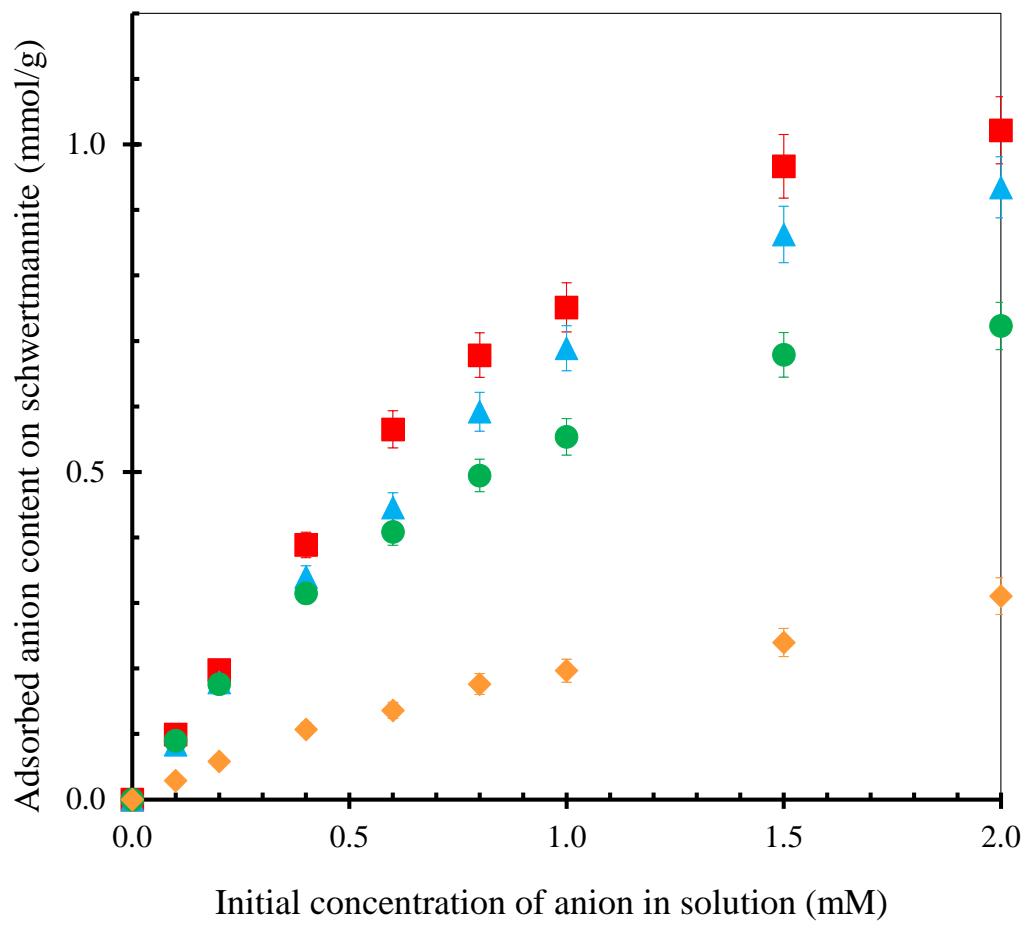

Figure 1. Adsorbed anion contents on schwertmannite as function of the initial concentration of anion in solution ( $\square$ : Arsenate, $\triangle$ : Phosphate, $\bigcirc$ : Chromate and $\diamond$ : Selenate). 

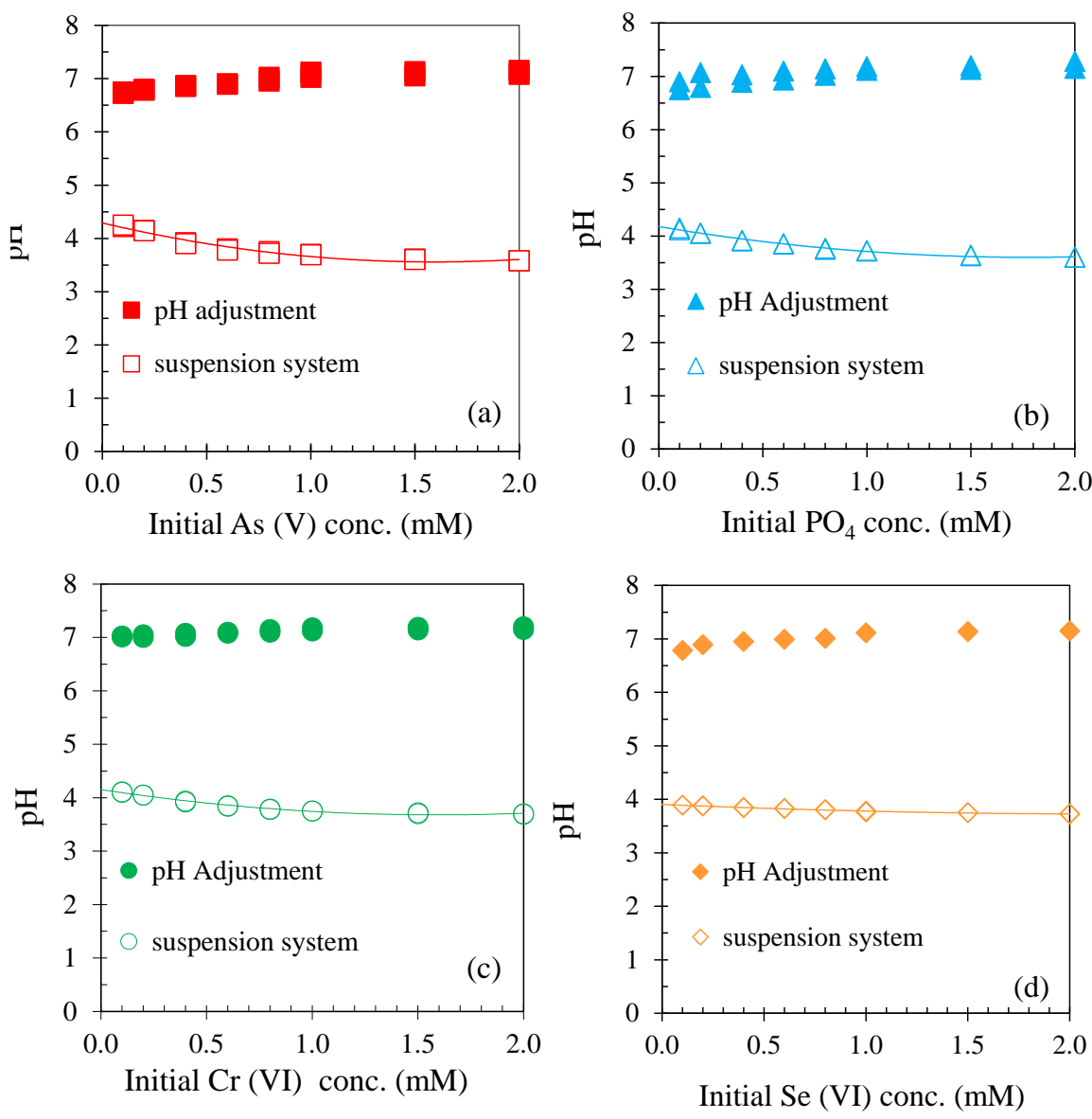

Figure 2. Changes in $\mathrm{pH}$ of the solution at the different initial concentration of anions during adsorption processes; (a) Arsenate, (b) Phosphate, (c) Chromate and (d) Selenate.
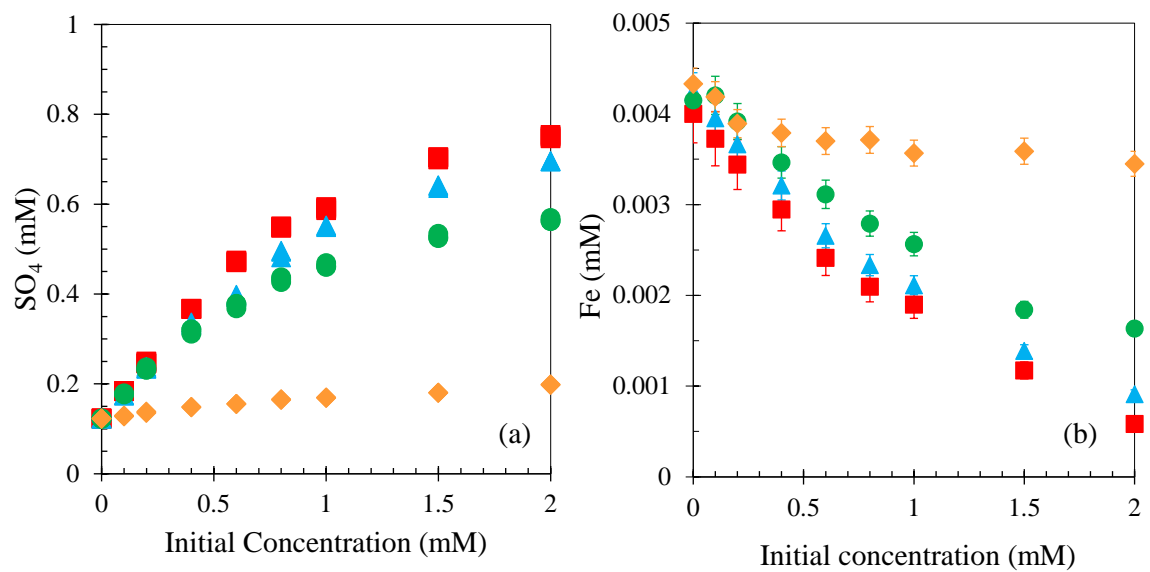

Figure 3. Related $\mathrm{SO}_{4}$ (a) and $\mathrm{Fe}$ (b) concentrations from schwertmannite as function of the initial concentration of anions during adsorption process ( $\square$ : Arsenate, $\Delta$ : Phosphate, : Chromate and $\diamond$ : Selenate).

anions in the solution (Figure 3(b)). The decreasing ratios were different among the anions in the following order, arsenate $\geq$ phosphate $>$ chromate $\gg$ selenite.

The zeta potentials of schwertmannite before and after adsorption of the anions were measured at different pHs (Figure 4). Schwertmannite before ad- 


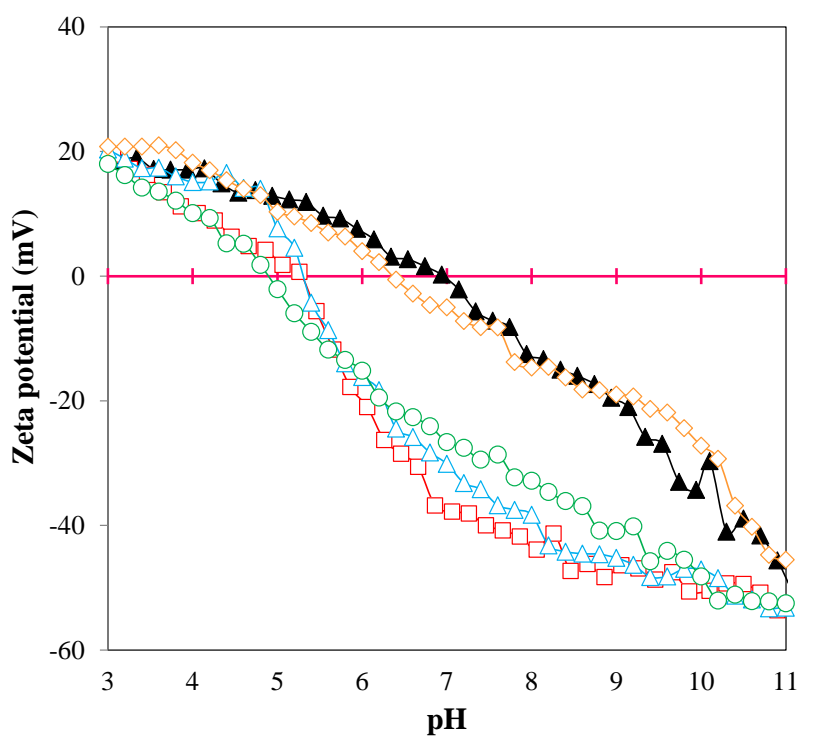

Figure 4. Changes in zeta potential of schwertmannite before and after adsorption with different oxyanions ( $\boldsymbol{\Delta}$ : sulfate, $\square$ : Arsenate, $\triangle$ : Phosphate, $\bigcirc$ : Chromate and $\diamond$ : Selenate.).

sorption, sulfate-schwertmannite, has a Point of Zero Charge (PZC) at around 7. The schwertmannite has positive and negative potentials at $\mathrm{pH}$ less and more than 7. Schwertmannite with selenate changes similar to that of schwertmannite with sulfate. PZC of selenite-schwertmannite is at around 6.2. Schwertmannite with arsenate, phosphate, and chromate showed different changes from that of schwertmannite with sulfate with a PZC at around 5. Among arsenate, phosphate, and chromate, schwertmannite with chromate changes is slightly different curve at $\mathrm{pH}$ range between 6 and 10 with less negative potentials.

\subsection{Aging Experiments}

From the results of the aging experiments, the XRD patterns of samples clearly indicated the difference in the stability of schwertmannite with different oxyanions and aging times as shown in Figure 5. In schwertmannite with sulfate ions (pure schwertmannite), the peaks from goethite appeared after 7 days, while the peaks from goethite appeared after 14 days in schwertmannite with selenate. In schwertmannite with chromate, the XRD pattern showed peaks form goethite after 30 days. There are no differences in the XRD patterns for schwertmannite with arsenate and phosphate even after 30 days. In comparison with pure schwertmannite, transformation to goethite was retarded for schwertmannite after adsorption with selenate, chromate, phosphate, and arsenate. The degree of retardation in transformation to goethite decreased as: arsenate $=$ phosphate $>$ chromate $>$ selenate $>$ sulfate.

\section{Discussion}

\subsection{Difference of Adsorption with Different Anions}

Among the oxyanions, there are differences in the adsorption capacity. As men- 


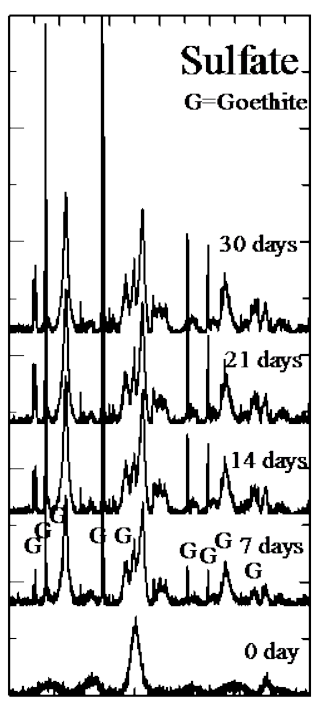

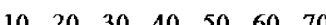

${ }^{\circ} 2 \theta \mathrm{CuK \alpha}$

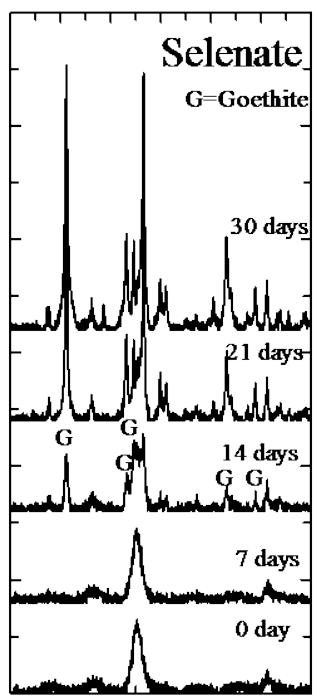

${ }^{\circ} 2 \theta \mathrm{CuK} \alpha$
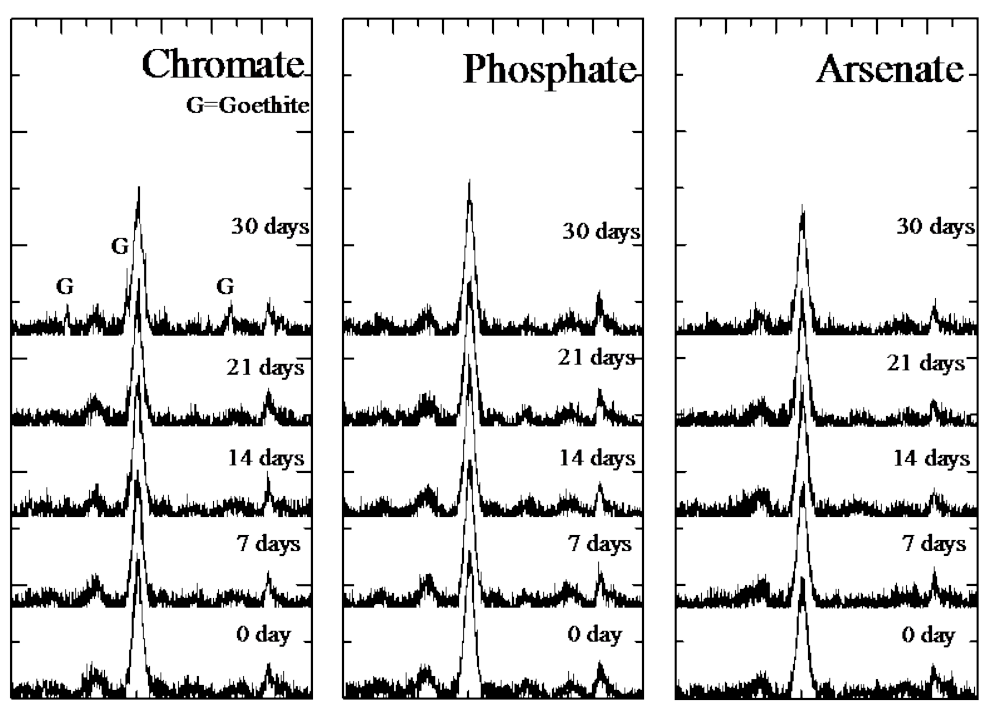

$10 \quad 20 \quad 30 \quad 40 \quad 50 \quad 60 \quad 701$

${ }^{\circ} 2 \theta \mathrm{CuK} \alpha$

${ }^{\circ} 2 \theta \mathrm{CuK} \alpha$

${ }^{\circ} 2 \theta \mathrm{CuK} \alpha$

Figure 5. X-ray diffractogram of the synthetic schwertmannite and schwertmannite after adsorption of each oxyanion with different aging times.

tioned above, the selectivity of oxyanion adsorption on schwertmannite decreases in the following order: arsenate $\geq$ phosphate $>$ chromate $\gg$ selenate. At the $\mathrm{pH}$ after the reaction, the dominant species of the oxyanions were $\mathrm{H}_{2} \mathrm{AsO}_{4}^{-}$, $\mathrm{H}_{2} \mathrm{PO}_{4}^{-}, \mathrm{HCrO}_{4}^{-}$and $\mathrm{SeO}_{4}^{2-}$ from the thermodynamic calculation by the Geochemist's workbench (GWB) using the latest thermodynamic database released from Laurence Livermore National Laboratory in USA. From the comparison of anion adsorptions, strong base anions can achieve a strong adsorption with the schwertmannite surface, and with high adsorption capacity.

The changes in the Zeta potential after adsorption by arsenate, phosphate and chromate were very different from the adsorption by selenate and that of original schwertmannite. This difference implies that the adsorption mechanism on schwertmannite for arsenate, phosphate and chromate is different from selenate and sulfate. The curves of the Zeta potential after adsorption for oxyanions shifted to negative. The degree of the shift increased in the following order, selenate $\ll$ chromate $<$ phosphate $<$ arsenate. This shift may be attributed to interaction between oxyanions and the schwertmannite surface. An inner-sphere complexation induced the modification of surface charge of the minerals. The inner-sphere complexation with anions makes the surface charge negative. Therefore, we may assume that arsenate, phosphate and chromate form inner-sphere complexes with the surface of schwertmannite. The selenate and sulfate form outer-sphere complexes with the surface of the schwertmannite.

\subsection{Anion-Exchange with Different Anions}

As described above, adsorption of oxyanions with schwertmannite such as with arsenate, phosphate and chromate is represented by the release of $\mathrm{SO}_{4}^{2-}$ and proton in the adsorption process (Figure 2 and Figure 3), These stoichiometri- 
cion-exchange are confirmed by a plot in Figure 6, which is from the previous study for the case of sorption of $\mathrm{As}(\mathrm{III})$ and $\mathrm{As}(\mathrm{V})$ onto schwertmannite [22].

The quantity of released protons was estimated from the differences in proton concentrations which were calculated from the speciation analytical by REACT in GWB package [23]. From the slope of the regression line in Figure 6, schwertmannite released $0.61 \mathrm{mmol}$ of $\mathrm{SO}_{4}{ }^{2-}$ after $1 \mathrm{mmol}$ of $\mathrm{As}(\mathrm{V})$ adsorption. This value is similar to the value previously reported by Fukushi et al. [19]. Overall, the anion-exchange reaction can be expressed as below:

$$
\mathrm{Sch}+\mathrm{As} \rightarrow \mathrm{As}-\mathrm{Sch}+0.61 \mathrm{SO}_{4}^{2-}+0.22 \mathrm{H}^{+}
$$

where Schindicates schwertmannite with sulfate and As-Sch is the schwertmannite with arsenate. Similarly, the anion-exchange reaction of phosphate with sulfate and chromate with sulfate become express as follows, respectively.

$$
\mathrm{Sch}+\mathrm{PO}_{4} \rightarrow \mathrm{PO}_{4}-\mathrm{Sch}+0.61 \mathrm{SO}_{4}^{2-}+0.21 \mathrm{H}^{+}
$$

and

$$
\mathrm{Sch}+\mathrm{Cr} \rightarrow \mathrm{Cr}-\mathrm{Sch}+0.61 \mathrm{SO}_{4}^{2-}+0.21 \mathrm{H}^{+}
$$
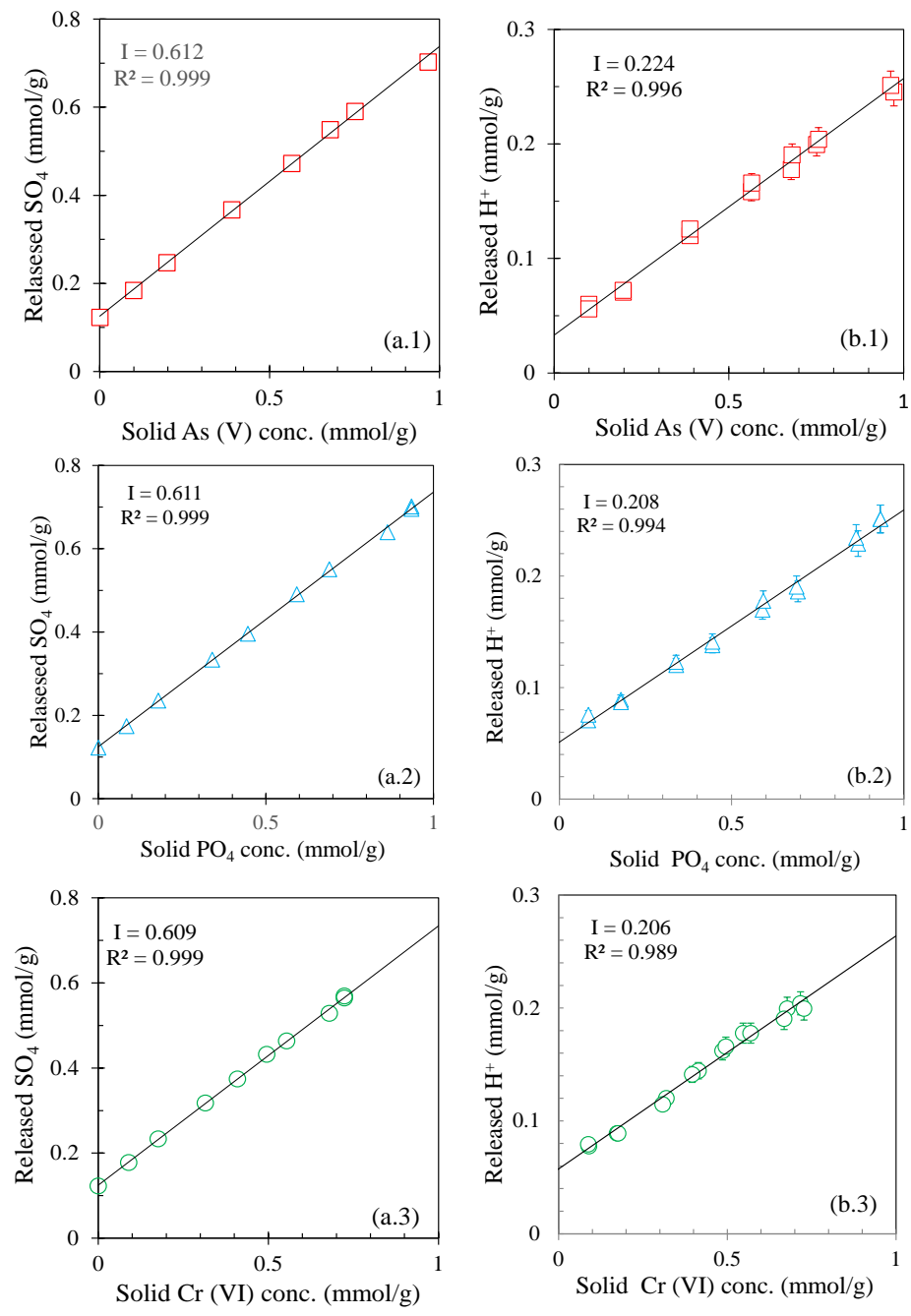

Figure 6. Relationship between the amount solid-phase (oxyanions) concentration with (a) released $\mathrm{SO}_{4}$ and (b) released of $\mathrm{H}^{+}$. 
In this study, selenate adsorption on schwertmannite was not considered to be an ion-exchange with sulfate because the capacity of selenate adsorption is limited.

Bigham, et al. [13] reported the chemical formula of schwertmannite as follows:

$$
\mathrm{Fe}_{8} \mathrm{O}_{8}(\mathrm{OH})_{8-2 x}\left(\mathrm{SO}_{4}\right)_{x}
$$

where $x$ is $1<x<1.75$. The mole numbers of $\mathrm{SO}_{4}$ and mole number of each oxyanion in chemical formula were calculated by setting the mole number of $\mathrm{Fe}$ equal to 8 in Tables 1-3 for As-Sch, $\mathrm{PO}_{4}$-Sch, and Cr-Sch, respectively. As shown

Table 1. Chemical composition of schwertmannite adsorbed by arsenate.

\begin{tabular}{|c|c|c|c|c|c|c|c|c|c|}
\hline & & $\mathrm{Fe}$ & $\mathrm{SO}_{4}$ & As & $\mathrm{Fe}$ & $\mathrm{H}_{2} \mathrm{AsO}_{4}$ & $\mathrm{SO}_{4}$ & $\mathrm{Cal} \mathrm{SO} 4$ & $\mathrm{Cal} \mathrm{OH}$ \\
\hline$x$ & As $/($ As $+\mathrm{S})$ & $\mathrm{mmol} / \mathrm{g}$ & $\mathrm{mmol} / \mathrm{g}$ & $\mathrm{mmol} / \mathrm{g}$ & $\begin{array}{c}\text { no./unit } \\
\text { cell }\end{array}$ & $\begin{array}{c}\text { no./unit } \\
\text { cell }\end{array}$ & $\begin{array}{c}\text { no./unit } \\
\text { cell }\end{array}$ & $\begin{array}{c}\text { no./unit } \\
\text { cell }\end{array}$ & $\begin{array}{c}\text { no./unit } \\
\text { cell }\end{array}$ \\
\hline 0.00 & 0.00 & 7.49 & 1.46 & 0.00 & 8 & 0.00 & 1.56 & 1.56 & 0.00 \\
\hline 0.01 & 0.01 & 7.49 & 1.46 & 0.01 & 8 & 0.01 & 1.55 & 1.55 & 0.00 \\
\hline 0.05 & 0.03 & 7.49 & 1.43 & 0.05 & 8 & 0.05 & 1.53 & 1.52 & 0.01 \\
\hline 0.10 & 0.07 & 7.49 & 1.40 & 0.10 & 8 & 0.11 & 1.49 & 1.49 & 0.02 \\
\hline 0.25 & 0.16 & 7.49 & 1.31 & 0.26 & 8 & 0.27 & 1.39 & 1.39 & 0.06 \\
\hline 0.50 & 0.31 & 7.49 & 1.15 & 0.51 & 8 & 0.55 & 1.23 & 1.22 & 0.11 \\
\hline 0.75 & 0.44 & 7.49 & 0.99 & 0.77 & 8 & 0.82 & 1.06 & 1.06 & 0.17 \\
\hline 0.90 & 0.51 & 7.49 & 0.90 & 0.92 & 8 & 0.98 & 0.96 & 0.96 & 0.21 \\
\hline 0.95 & 0.53 & 7.49 & 0.87 & 0.97 & 8 & 1.04 & 0.92 & 0.92 & 0.22 \\
\hline 0.99 & 0.55 & 7.49 & 0.84 & 1.01 & 8 & 1.08 & 0.90 & 0.90 & 0.23 \\
\hline 1.00 & 0.55 & 7.49 & 0.83 & 1.02 & 8 & 1.09 & 0.89 & 0.89 & 0.23 \\
\hline
\end{tabular}

Table 2. Chemial composition of schwertmannite adsorbed by phosphate.

\begin{tabular}{cccccccccc}
\hline & & $\mathrm{Fe}$ & $\mathrm{SO}_{4}$ & $\mathrm{PO}_{4}$ & $\mathrm{Fe}$ & $\mathrm{H}_{2} \mathrm{PO}_{4}$ & $\mathrm{SO}_{4}$ & $\mathrm{Cal} \mathrm{SO} \mathrm{Cal} \mathrm{OH}$ \\
\cline { 3 - 9 }$x$ & $\mathrm{PO}_{4} /\left(\mathrm{PO}_{4}+\mathrm{S}\right)$ & $\mathrm{mmol} / \mathrm{g}$ & $\mathrm{mmol} / \mathrm{g}$ & $\mathrm{mmol} / \mathrm{g}$ & $\begin{array}{c}\text { no./unit } \\
\text { cell }\end{array}$ & $\begin{array}{c}\text { no./unit } \\
\text { cell }\end{array}$ & $\begin{array}{c}\text { no./unit } \\
\text { cell }\end{array}$ & $\begin{array}{c}\text { no./unit } \\
\text { cell }\end{array}$ & $\begin{array}{c}\text { no./unit } \\
\text { cell }\end{array}$ \\
\hline 0.00 & 0.00 & 7.49 & 1.46 & 0.00 & 8 & 0.00 & 1.56 & 1.56 & 0.00 \\
0.01 & 0.06 & 7.49 & 1.41 & 0.08 & 8 & 0.09 & 1.50 & 1.55 & 0.00 \\
0.05 & 0.12 & 7.49 & 1.35 & 0.18 & 8 & 0.19 & 1.44 & 1.53 & 0.01 \\
0.10 & 0.21 & 7.49 & 1.25 & 0.34 & 8 & 0.36 & 1.33 & 1.50 & 0.02 \\
0.25 & 0.27 & 7.49 & 1.19 & 0.45 & 8 & 0.48 & 1.27 & 1.41 & 0.05 \\
0.50 & 0.30 & 7.49 & 1.09 & 0.47 & 8 & 0.50 & 1.17 & 1.26 & 0.10 \\
0.75 & 0.40 & 7.49 & 1.03 & 0.70 & 8 & 0.75 & 1.10 & 1.10 & 0.15 \\
0.90 & 0.46 & 7.49 & 0.99 & 0.84 & 8 & 0.90 & 1.06 & 1.01 & 0.17 \\
0.95 & 0.46 & 7.49 & 0.94 & 0.88 & 8 & 0.94 & 1.01 & 0.98 & 0.18 \\
0.99 & 0.49 & 7.49 & 0.90 & 0.92 & 8 & 0.98 & 0.96 & 0.96 & 0.19 \\
1.00 & 0.51 & 7.49 & 0.89 & 0.93 & 8 & 1.00 & 0.95 & 0.95 & 0.19 \\
\hline
\end{tabular}


Table 3. Chemical composition of schwertmannite adsorbed by chromate

\begin{tabular}{cccccccccc}
\hline & & $\mathrm{Fe}$ & $\mathrm{SO}_{4}$ & $\mathrm{Cr}$ & $\mathrm{Fe}$ & $\mathrm{HCrO}_{4}$ & $\mathrm{SO}_{4}$ & $\mathrm{Cal} \mathrm{SO}_{4}$ & $\mathrm{Cal} \mathrm{OH}$ \\
\cline { 3 - 10 }$x$ & $\mathrm{Cr} /(\mathrm{Cr}+\mathrm{S})$ & $\mathrm{mmol} / \mathrm{g}$ & $\mathrm{mmol} / \mathrm{g}$ & $\mathrm{mmol} / \mathrm{g}$ & $\begin{array}{c}\text { no./unit } \\
\text { cell }\end{array}$ & $\begin{array}{c}\text { no./unit } \\
\text { cell }\end{array}$ & $\begin{array}{c}\text { no./unit } \\
\text { cell }\end{array}$ & $\begin{array}{c}\text { no./unit } \\
\text { cell }\end{array}$ & $\begin{array}{c}\text { no./unit } \\
\text { cell }\end{array}$ \\
\hline 0.00 & 0.00 & 7.49 & 1.46 & 0.00 & 8 & 0.00 & 1.56 & 1.56 & 0.00 \\
0.01 & 0.06 & 7.49 & 1.40 & 0.09 & 8 & 0.10 & 1.50 & 1.55 & 0.00 \\
0.05 & 0.12 & 7.49 & 1.35 & 0.18 & 8 & 0.19 & 1.44 & 1.53 & 0.01 \\
0.10 & 0.20 & 7.49 & 1.26 & 0.31 & 8 & 0.34 & 1.35 & 1.51 & 0.01 \\
0.25 & 0.25 & 7.49 & 1.21 & 0.41 & 8 & 0.44 & 1.29 & 1.44 & 0.04 \\
0.50 & 0.30 & 7.49 & 1.15 & 0.49 & 8 & 0.53 & 1.23 & 1.32 & 0.07 \\
0.75 & 0.33 & 7.49 & 1.12 & 0.55 & 8 & 0.59 & 1.19 & 1.21 & 0.11 \\
0.90 & 0.37 & 7.49 & 1.09 & 0.65 & 8 & 0.69 & 1.16 & 1.14 & 0.13 \\
0.95 & 0.39 & 7.49 & 1.08 & 0.68 & 8 & 0.73 & 1.15 & 1.11 & 0.14 \\
0.99 & 0.40 & 7.49 & 1.05 & 0.69 & 8 & 0.74 & 1.13 & 1.09 & 0.15 \\
1.00 & 0.42 & 7.49 & 1.02 & 0.72 & 8 & 0.77 & 1.09 & 1.09 & 0.15 \\
\hline
\end{tabular}

in the composition of schwertmannite and schwertmannite adsorbed oxyanions; the maximum adsorbed oxyanions are about half of $\mathrm{SO}_{4}$ which remains in schwertmannite. In the natural states based on field observations it was established that the $\mathrm{As} /(\mathrm{As}+\mathrm{S})$ ratio was 0.7 , by using synthetic co-precipitation prepared with different amounts of $\mathrm{As}(\mathrm{V})$, the result showed that half of the $\mathrm{SO}_{4}$ is basically need to stabilize the structure of schwertmannite whereas the other half functions as exchangeable anions during $\mathrm{As}(\mathrm{V})$ adsorption [24].

From the chemical composition of schwertmannite and schwertmannite adsorbed by oxyanions, the mole numbers of $\mathrm{SO}_{4}$ which could be exchanged are $0.67,0.61$ and 0.47 which correspond to arsenate, phosphate and chromate adsorption, respectively. Therefore, schwertmannite with the maximum amount of oxyanions was as follows:

$$
\begin{gathered}
\mathrm{Fe}_{8} \mathrm{O}_{8}(\mathrm{OH})_{4.88}^{\mathrm{St}}\left(\mathrm{SO}_{4}\right)_{0.89}^{\mathrm{St}}\left(\mathrm{H}_{2} \mathrm{AsO}_{4}\right)_{1.09}^{\mathrm{Ex}}(\mathrm{OH})_{0.23}^{\mathrm{Ex}} \\
\mathrm{Fe}_{8} \mathrm{O}_{8}(\mathrm{OH})_{4.88}^{\mathrm{St}}\left(\mathrm{SO}_{4}\right)_{0.95}^{\mathrm{St}}\left(\mathrm{H}_{2} \mathrm{PO}_{4}\right)^{\mathrm{Ex}}(\mathrm{OH})_{0.19}^{\mathrm{Ex}} \\
\mathrm{Fe}_{8} \mathrm{O}_{8}(\mathrm{OH})_{4.88}^{\mathrm{St}}\left(\mathrm{SO}_{4}\right)_{1.09}^{\mathrm{St}}\left(\mathrm{HCrO}_{4}\right)_{0.77}^{\mathrm{Ex}}(\mathrm{OH})_{0.15}^{\mathrm{Ex}}
\end{gathered}
$$

where St is the principal structural component and Ex is the exchangeable component. This shows that schwertmannite sorbing arsenate (Sch-As), phosphate $\left(\mathrm{Sch}-\mathrm{PO}_{4}\right)$ and chromate (Sch-Cr), which all behave as a solid-solution, are represented by the following chemical formulas, respectively

$$
\begin{gathered}
\mathrm{Fe}_{8} \mathrm{O}_{8}(\mathrm{OH})_{4.88}^{\mathrm{St}}\left(\mathrm{SO}_{4}\right)_{0.89}^{\mathrm{St}}\left(\mathrm{SO}_{4}\right)_{0.67-0.67 x}^{\mathrm{Ex}}\left(\mathrm{H}_{2} \mathrm{AsO}_{4}\right)_{1.09 x}^{\mathrm{Ex}}(\mathrm{OH})_{0.23 x}^{\mathrm{Ex}} \\
\mathrm{Fe}_{8} \mathrm{O}_{8}(\mathrm{OH})_{4.88}^{\mathrm{St}}\left(\mathrm{SO}_{4}\right)_{0.95}^{\mathrm{St}}\left(\mathrm{SO}_{4}\right)_{0.61-0.61 x}^{\mathrm{Ex}}\left(\mathrm{H}_{2} \mathrm{PO}_{4}\right)_{x}^{\mathrm{Ex}}(\mathrm{OH})_{0.19 x}^{\mathrm{Ex}} \\
\mathrm{Fe}_{8} \mathrm{O}_{8}(\mathrm{OH})_{4.88}^{\mathrm{St}}\left(\mathrm{SO}_{4}\right)_{1.09}^{\mathrm{St}}\left(\mathrm{SO}_{4}\right)_{0.47-0.47 x}^{\mathrm{Ex}}\left(\mathrm{HCrO}_{4}\right)_{0.77 x}^{\mathrm{Ex}}(\mathrm{OH})_{0.15 x}^{\mathrm{Ex}}
\end{gathered}
$$

In the formula above, $x$ is the mole fraction of Sch-As, Sch- $\mathrm{PO}_{4}$ and Sch-Cr, respectively. 


\subsection{Estimating the Equilibrium Constant for Anion-Exchange Reaction}

The exchange reaction is described by an equilibrium constant and the distribution coefficient ordinarily expressed separately for solid and aqueous solutions [25] [26] [27]. The equilibrium constant can be used to predict the amount of an element in the solid phase when the solution chemistry is known. The anion-exchange reaction from Equations (1)-(3) can then be formulated with end-number composition, similar to the previous work by Fukushi et al. [19].

$$
\begin{aligned}
& \mathrm{Fe}_{8} \mathrm{O}_{8}(\mathrm{OH})_{4.88}^{\mathrm{St}}\left(\mathrm{SO}_{4}\right)_{0.89}^{\mathrm{St}}\left(\mathrm{SO}_{4}\right)_{0.67}^{\mathrm{Ex}}+1.09 \mathrm{H}_{2} \mathrm{AsO}_{4}^{-}+0.23 \mathrm{H}_{2} \mathrm{O} \\
& \rightarrow \mathrm{Fe}_{8} \mathrm{O}_{8}(\mathrm{OH})_{4.88}^{\mathrm{St}}\left(\mathrm{SO}_{4}\right)_{0.89}^{\mathrm{St}}\left(\mathrm{H}_{2} \mathrm{AsO}_{4}\right)_{1.09}^{\mathrm{Ex}}(\mathrm{OH})_{0.23}^{\mathrm{Ex}}+0.67 \mathrm{SO}_{4}^{2-}+0.23 \mathrm{H}^{+} \\
& \mathrm{Fe}_{8} \mathrm{O}_{8}(\mathrm{OH})_{4.88}^{\mathrm{St}}\left(\mathrm{SO}_{4}\right)_{0.95}^{\mathrm{St}}\left(\mathrm{SO}_{4}\right)_{0.61}^{\mathrm{Ex}}+\mathrm{H}_{2} \mathrm{PO}_{4}^{-}+0.19 \mathrm{H}_{2} \mathrm{O} \\
& \rightarrow \mathrm{Fe}_{8} \mathrm{O}_{8}(\mathrm{OH})_{4.88}^{\mathrm{St}}\left(\mathrm{SO}_{4}\right)_{0.95}^{\mathrm{St}}\left(\mathrm{H}_{2} \mathrm{PO}_{4}\right)_{1}^{\mathrm{Ex}}(\mathrm{OH})_{0.23}^{\mathrm{Ex}}+0.61 \mathrm{SO}_{4}^{2-}+0.19 \mathrm{H}^{+} \\
& \mathrm{Fe}_{8} \mathrm{O}_{8}(\mathrm{OH})_{4.88}^{\mathrm{St}}\left(\mathrm{SO}_{4}\right)_{1.09}^{\mathrm{St}}\left(\mathrm{SO}_{4}\right)_{0.47}^{\mathrm{Ex}}+0.77 \mathrm{HCrO}_{4}^{-}+0.15 \mathrm{H}_{2} \mathrm{O} \\
& \rightarrow \mathrm{Fe}_{8} \mathrm{O}_{8}(\mathrm{OH})_{4.88}^{\mathrm{St}}\left(\mathrm{SO}_{4}\right)_{1.09}^{\mathrm{St}}\left(\mathrm{HCrO}_{4}\right)_{0.77}^{\mathrm{Ex}}(\mathrm{OH})_{0.15}^{\mathrm{Ex}}+0.47 \mathrm{SO}_{4}^{2-}+0.15 \mathrm{H}^{+}
\end{aligned}
$$

The equilibrium constant for Equations (4)-(6) are represented below:

$$
\begin{aligned}
& K_{\mathrm{ex}}=\frac{a_{\mathrm{SO}_{4}^{2-}}^{0.67} a_{\mathrm{H}^{+}}^{0.23} x_{\text {sch-As }} \gamma_{\text {sch-As }}}{a_{\mathrm{H}_{2} \mathrm{AsO}_{4}^{-}}^{1.09} x_{\mathrm{sch}} \gamma_{\mathrm{sch}}} \\
& K_{\mathrm{ex}}=\frac{a_{\mathrm{SO}_{4}^{2-}}^{0.61} a_{\mathrm{H}^{+}}^{0.19} x_{\text {sch- } \mathrm{PO}_{4}} \gamma_{\text {sch- } \mathrm{PO}_{4}}}{a_{\mathrm{H}_{2} \mathrm{PO}_{4}^{-}}^{1} x_{\mathrm{sch}} \gamma_{\mathrm{sch}}} \\
& K_{\mathrm{ex}}=\frac{a_{\mathrm{sO}_{4}^{2-}}^{0.47} a_{\mathrm{H}^{+}}^{0.15} x_{\mathrm{sch}-\mathrm{Cr}} \gamma_{\text {sch-Cr }}}{a_{\mathrm{HCrO}_{4}^{-}}^{0.77} x_{\mathrm{sch}} \gamma_{\text {sch }}}
\end{aligned}
$$

where $X_{\text {sch }} \cdot X_{\text {sch-As }}, X_{\text {sch-PO }}$ and $X_{\text {sch-Cr }}$ shows the mole fraction of schwertmannite, Sch-As, Sch- $\mathrm{PO}_{4}, \mathrm{Sch}-\mathrm{Cr}$, respectively in the solid solution, whereas $\gamma_{\text {sch }}, \gamma_{\text {sch-As }}, \gamma_{\text {sch-PO }}$ and $\gamma_{\text {sch-Cr }}$ symbolized the activity coefficient of components of schwertmannite and schwertmannite adsorbed oxyanions. Equations (7)-(9) could be converted to:

$$
\begin{aligned}
& K_{\mathrm{ex}} \frac{\gamma_{\mathrm{sch}}}{\gamma_{\mathrm{sch}-\mathrm{As}}}=\frac{a_{\mathrm{sO}_{4}^{2-}}^{0.67} a_{\mathrm{H}^{+}}^{0.23} \mathrm{x}_{\mathrm{sch}-\mathrm{As}}}{a_{\mathrm{H}_{2} \mathrm{AsO}_{4}^{-}}^{1.09} \mathrm{X}_{\mathrm{sch}}}=K_{d} \\
& K_{\text {ex }} \frac{\gamma_{\text {sch }}}{\gamma_{\text {sch- }-\mathrm{PO}_{4}}}=\frac{a_{\mathrm{SO}_{4}^{2-}}^{0.61} a_{\mathrm{H}^{+}}^{0.19} \mathrm{X}_{\mathrm{sch}-\mathrm{PO}_{4}}}{a_{\mathrm{H}_{2} \mathrm{PO}_{4}^{-}}^{1} \mathrm{X}_{\mathrm{sch}}}=K_{d} \\
& K_{\mathrm{ex}} \frac{\gamma_{\mathrm{sch}}}{\gamma_{\text {sch-Cr }}}=\frac{a_{\mathrm{SO}_{4}^{2-} a_{\mathrm{H}^{+}}^{0.15} \mathrm{X}_{\mathrm{sch}-\mathrm{Cr}}}^{a_{\mathrm{HCrO}_{4}^{-}}^{0.77} \mathrm{x}_{\mathrm{sch}}}}{K_{d}}
\end{aligned}
$$

where $K_{d}$ is the distribution coefficient. The distribution coefficients were calculated by replacing the solution activities of each dissolved species and mole fraction of schwertmannite. That adsorbed by oxyanions as shown in Equation (10)-(12) were used input data, from Tables 4-6. The average distribution coef- 
Table 4. Activities of dissolove solution speciation and mole fraction of schwertmannite adsorbed by arsenate.

\begin{tabular}{ccccc}
\hline$x$ & $\log (\mathrm{As})$ & $\log \left(\mathrm{SO}_{4}^{2-}\right)$ & $\log \left(\mathrm{Fe}^{3+}\right)$ & $\log \left(\mathrm{H}^{+}\right)$ \\
\hline 0.00 & & -4.10 & -8.31 & -4.25 \\
0.01 & -7.75 & -4.11 & -8.20 & -4.14 \\
0.05 & -7.66 & -4.03 & -7.83 & -3.90 \\
0.10 & -6.28 & -3.95 & -7.70 & -3.78 \\
0.25 & -5.76 & -3.77 & -7.67 & -3.72 \\
0.50 & -5.36 & -3.58 & -7.68 & -3.70 \\
0.75 & -4.89 & -3.45 & -7.62 & -3.63 \\
0.90 & -4.42 & -3.39 & -7.80 & -3.60 \\
0.95 & -4.10 & -3.37 & -7.97 & -3.58 \\
0.99 & -3.59 & -3.35 & -7.97 & -3.55 \\
1.00 & -3.50 & -3.33 & -7.97 & -3.50 \\
\hline
\end{tabular}

Table 5. Activities of dissolve solution speciation and mole fraction of schwertmannite adsorbed by phosphate.

\begin{tabular}{ccccc}
\hline$x$ & $\log \left(\mathrm{PO}_{4}\right)$ & $\log \left(\mathrm{SO}_{4}^{2-}\right)$ & $\log \left(\mathrm{Fe}^{3+}\right)$ & $\log \left(\mathrm{H}^{+}\right)$ \\
\hline 0.00 & & -4.12 & -8.53 & -4.35 \\
0.01 & -7.65 & -4.10 & -8.13 & -4.12 \\
0.05 & -7.57 & -4.03 & -8.04 & -4.06 \\
0.10 & -5.30 & -3.96 & -7.80 & -3.91 \\
0.25 & -4.71 & -3.80 & -7.74 & -3.85 \\
0.50 & -4.35 & -3.61 & -7.65 & -3.75 \\
0.75 & -4.17 & -3.48 & -7.70 & -3.72 \\
0.90 & -4.09 & -3.42 & -7.62 & -3.63 \\
0.95 & -4.06 & -3.39 & -7.60 & -3.60 \\
0.99 & -3.50 & -3.39 & -7.82 & -3.58 \\
1.00 & -3.45 & -3.39 & -7.88 & -3.55 \\
\hline
\end{tabular}

Table 6. Activities of dissolve solution speciation and mole fraction of schwertmannite adsorbed by chromate.

\begin{tabular}{ccccc}
\hline$x$ & $\log (\mathrm{Cr})$ & $\log \left(\mathrm{SO}_{4}^{2-}\right)$ & $\log \left(\mathrm{Fe}^{3+}\right)$ & $\log \left(\mathrm{H}^{+}\right)$ \\
\hline 0.00 & & -4.10 & -8.29 & -4.25 \\
0.01 & -7.14 & -4.11 & -8.13 & -4.10 \\
0.05 & -5.84 & -4.05 & -7.98 & -4.05 \\
0.10 & -5.30 & -3.99 & -7.98 & -3.92 \\
0.25 & -4.57 & -3.85 & -7.77 & -3.84 \\
0.50 & -4.02 & -3.68 & -7.67 & -3.80 \\
0.75 & -3.69 & -3.56 & -7.65 & -3.77 \\
0.90 & -3.54 & -3.50 & -7.70 & -3.75 \\
0.95 & -3.47 & -3.48 & -7.76 & -3.72 \\
0.99 & -3.39 & -3.47 & -7.75 & -3.70 \\
1.00 & -3.31 & -3.47 & -7.73 & -3.69 \\
\hline
\end{tabular}


ficient, $\log K_{d}$ is $2.82 \pm 0.45,2.23 \pm 0.57$ and $1.38 \pm 0.14$ for Sch-As, Sch- $\mathrm{PO}_{4}$, Sch-Cr, respectively.

According to previous study by Fukushi et al. [19], the $K_{d}$ value was very similar to $K_{\mathrm{ex}}$, because in an ideal solid solution model it is assumed that the activity coefficient of this system is unity. Hence, the high value of the equilibrium constant for the anion-exchange reaction corresponds to the ratio of dissolution reaction of the mineral and mineral adsorbed by trace element. At high equilibrium constants, the adsorption capacity was highly adsorbed onto schwertmannite.

\subsection{Stability of Schwertmannite with Different Oxyanions}

The transformation process of schwertmannite to goethite involves dissolution and re-precipitation processes. The results from the calculation of solubility show that a low solubility suggests a high stability of the mineral [28]. In the previous studies, the stability of the mineral was described from consideration of the activity of dissolved species in aqueous solution; this was used to estimate the solubility products to calculate the stability minerals [29] [30]. This corresponds to the experimental results where the association of the solubility between schwertmannite and schwertmannite adsorbed by oxyanions could be a result of the equilibrium constant of the exchange reaction from Equations (7)-(9). [31] [32] [33] [34]. The dissolution reaction equation of the synthesized schwertmannite can be expressed as:

$$
\mathrm{Fe}_{8} \mathrm{O}_{8}(\mathrm{OH})_{4.88}\left(\mathrm{SO}_{4}\right)_{1.56}+20.88 \mathrm{H}^{+} \leftrightarrow 8 \mathrm{Fe}^{3+}+1.56 \mathrm{SO}_{4}^{2-}+12.88 \mathrm{H}_{2} \mathrm{O}
$$

From Equation (13), the equilibrium constant of schwertmannite could be expressed by:

$$
K_{\text {sch }}=\frac{a_{\mathrm{Fe}^{3+}}^{8} a_{\mathrm{sO}_{4}^{2-}}^{1.56}}{a_{\mathrm{H}^{+}}^{20.88}}
$$

where, the activity of $\mathrm{H}_{2} \mathrm{O}$ and the mineral is unity. The dissolution reaction equation for schwertmannite which has adsorbed different kinds of oxyanions could be written by:

$$
\begin{aligned}
& \mathrm{Fe}_{8} \mathrm{O}_{8}(\mathrm{OH})_{4.88}\left(\mathrm{SO}_{4}\right)_{0.89}\left(\mathrm{H}_{2} \mathrm{AsO}_{4}\right)_{1.09}(\mathrm{OH})_{0.23}+21.11 \mathrm{H}^{+} \\
& \leftrightarrow 8 \mathrm{Fe}^{3+}+0.89 \mathrm{SO}_{4}^{2-}+1.09 \mathrm{H}_{2} \mathrm{AsO}_{4}+13.11 \mathrm{H}_{2} \mathrm{O} \\
& \mathrm{Fe}_{8} \mathrm{O}_{8}(\mathrm{OH})_{4.88}\left(\mathrm{SO}_{4}\right)_{0.95}\left(\mathrm{H}_{2} \mathrm{PO}_{4}\right)(\mathrm{OH})_{0.19}+21.07 \mathrm{H}^{+} \\
& \leftrightarrow 8 \mathrm{Fe}^{3+}+0.95 \mathrm{SO}_{4}^{2-}+\mathrm{H}_{2} \mathrm{PO}_{4}+13.07 \mathrm{H}_{2} \mathrm{O} \\
& \mathrm{Fe}_{8} \mathrm{O}_{8}(\mathrm{OH})_{4.88}\left(\mathrm{SO}_{4}\right)_{1.09}\left(\mathrm{HCrO}_{4}\right)_{0.77}(\mathrm{OH})_{0.15}+21.03 \mathrm{H}^{+} \\
& \leftrightarrow 8 \mathrm{Fe}^{3+}+1.09 \mathrm{SO}_{4}^{2-}+0.77 \mathrm{HCrO}_{4}+13.03 \mathrm{H}_{2} \mathrm{O}
\end{aligned}
$$

From Equations (15)-(17), the equilibrium constants could be represented by:

$$
K_{\text {sch-As }}=\frac{a_{\mathrm{Fe}^{3+}}^{8} a_{\mathrm{SO}_{4}^{2-}}^{0.89} a_{\mathrm{H}_{2} \mathrm{AsO}_{4}^{-}}^{1.09}}{a_{\mathrm{H}^{+}}^{21.11}}
$$




$$
\begin{gathered}
K_{\text {sch- } \mathrm{PO}_{4}}=\frac{a_{\mathrm{Fe}^{3+}}^{8} a_{\mathrm{SO}_{4}^{2-}}^{0.95} a_{\mathrm{H}_{2} \mathrm{PO}_{4}^{-}}^{1}}{a_{\mathrm{H}^{+}}^{21.07}} \\
K_{\text {sch-Cr }}=\frac{a_{\mathrm{Fe}^{3+}}^{8} a_{\mathrm{SO}_{4}^{2-}}^{1.09} a_{\mathrm{HCrO}_{4}^{-}}^{0.77}}{a_{\mathrm{H}^{+}}^{21.03}}
\end{gathered}
$$

As explained previously, $K_{d}$ corresponds to $K_{\mathrm{ex}}$ which is the equilibrium constant for anions-exchange reaction. Further, $K_{\mathrm{ex}}$ could be expressed as the ratio between the dissolution reaction of schwertmannite and schwertmannite adsorbed by different kinds of oxyanions as:

$$
\begin{aligned}
& K_{\mathrm{ex}-\mathrm{As}}=\frac{K_{\mathrm{sch}}}{K_{\mathrm{sch}-\mathrm{As}}} \\
& K_{\mathrm{ex}-\mathrm{PO}_{4}}=\frac{K_{\mathrm{sch}}}{K_{\mathrm{sch}-\mathrm{PO}_{4}}} \\
& K_{\mathrm{ex}-\mathrm{Cr}}=\frac{K_{\mathrm{sch}}}{K_{\mathrm{sch}-\mathrm{Cr}}}
\end{aligned}
$$

The $K_{\text {ex }}$ for the oxyanions indicate the relative solubility of each of the schwertmannite with oxyanions, which are compared with schwertmannite with sulfate (Table 7). The schwertmannite with arsenate has the lowest solubility and is the moststable phase among the one with other oxyanions. From Table 7, the relative solubility of schwertmannite with chromateis is smaller than that of schwertmannite with arsenate and phosphate. This implies that schwertmannite with chromate would be less stable than with arsenate and phosphate. This is consistent with the results of the aging experiments as shown in Figure 5. This is also consistent with the finding of the released Fe concentrations after the oxyanion adsorption as shown in Figure $3(\mathrm{~b})$. Consequently, adsorption by oxyanions with the higher selectivity may be expected to result in meta-stable schwertmannite becoming stable.

\section{Conclusions}

In this study, the adsorption and post adsorption behavior of schwertmannite with various kinds of oxyanions were investigated to determine the potential for cleaning-up of contaminated water with hazardous oxyanions and a safe disposal of spent schwertmannite. The result of the adsorption experiments shows that the selectivity of oxyanion adsorption on schwertmannite decreases as the following order: arsenate $\geq$ phosphate $>$ chromate $\gg$ selenate. The adsorption mechanism on schwertmannite with arsenate, phosphate and chromate is dif-

Table 7. Details of the solubility of schwertmannite with different kinds of oxyanions adsorbed.

\begin{tabular}{cccc}
\hline & \multicolumn{3}{c}{ Solubility of schwertmannite after adsorbed oxyanions } \\
\cline { 2 - 4 } & Arsenate & Phosphate & Chromate \\
\hline$K_{\mathrm{ex}}$ & $10^{2.82}$ & $10^{2.23}$ & $10^{1.38}$ \\
\hline
\end{tabular}


ferent from that with selenate and sulfate. Arsenate, phosphate and chromate ions form inner-sphere complexes with the surface of schwertmannite. The selenate and sulfate ions form outer-sphere complexes with the surface of schwertmannite. Strong base anions such as arsenate and phosphate can form innersphere complexes, which induces a strong adsorption with schwertmannite as well as provides a high adsorption capacity.

The stability of schwertmannite after the adsorption increased in the following order: sulfate $\cong$ selenate $\ll$ chromate $<$ phosphate $\cong$ arsenate. The solubility of schwertmannite with different oxyanions was calculated with solid solution theory. The solubility of schwertmannite decreased after adsorption of oxyanions with high selectivity. The solubility of schwertmannite with arsenate and phosphate is lower by two orders of magnitude than that with sulfate. Therefore, oxyanions with high selectivity can stabilize schwertmannite by decreasing the solubility of schwertmannite after adsorption of the oxyanions.

\section{Acknowledgements}

The authors wish to express gratitude to assisting technical staff and for the financial support from Laboratory of Environmental Geology, Faculty Engineering, Hokkaido University. The Japan International Cooperation Agency (JICA) provided financial support to KK during the PhD program.

\section{References}

[1] Kumar, A.R. and Riyazuddin, P. (2011) Speciation of Selenium in Groundwater: Seasonal Variations and Redox Transformations. Journal of Hazardous Materials, 192, 263-269.

[2] Kotaś, J. and Stasicka, Z. (2000) Chromium Occurrence in the Environment and Methods of Its Speciation. Environmental Pollution, 107, 263-283.

[3] Richard, F.C. and Bourg, A.C.M. (1991) Aqueous Geochemistry of Chromium: A Review. Water Research, 25, 807-816.

[4] Smedley, P.L. and Kinniburgh, D.G. (2002) A Review of the Source, Behaviour and Distribution of Arsenic in Natural Waters. Applied geochemistry, 17, 517-568.

[5] Saxena, V.K., Kumar, S. and Singh, V.S. (2004) Occurrence, Behaviour and Speciation of Arsenic in Groundwater. Current Science, 86, 281-284.

[6] Rubio, J., Souza, M.L. and Smith, R.W. (2002) Overview of Flotation as a Wastewater Treatment Technique. Mineral Engineering, 15,139-155.

[7] Mohan, D. and Pittman, C.U. (2007) Arsenic Removal from Water/Wastewater Using Adsorbents-A Critical Review. Journal of Hazardous Materials, 142, 1-53.

[8] Gonzalez, C.M., Hernandez, J., Parsons, J.G. and Gardea-Torresdey, J.L. (2010) A Study of the Removal of Selenite and Selenate from Aqueous Solutions Using a Magnetic Iron/Manganese Oxide Nanomaterial and ICP-MS. Microchemical Journal, 96, 324-329.

[9] Sawhney, B.L. (1972) Selective Sorption and Fixation of Cations by Clay Minerals: A Review. Clays and Clay Mineral, 20, 93-100. https://doi.org/10.1346/CCMN.1972.0200208

[10] Erdem, E., Karapinar, N. and Donat, R. (2004) The Removal of Heavy Metal Cations by Natural Zeolites. Journal Colloid and Interface Science, 280, 309-314. 
[11] Bigham, J.M., Schwertmann, U., Carlson, L. and Murad, E. (1990) A Poorly Crystallized Oxyhydroxysulfate of Iron Formed by Bacterial Oxidation of Fe(II) in Acid Mine Waters. Geochimica et Cosmochimica Acta, 54, 2743-2758.

[12] Bigham, J.M., Carlson, L. and Murad, E. (1994) Schwertmannite, a New Iron Oyhydroxy-Sulfate from Pyhasalmi, Filand and Other Localitites. Mineralogical Magazine, 58, 641-648. https://doi.org/10.1180/minmag.1994.058.393.14

[13] Bigham, J.M., Schwertmann, U., Traina, S.J., Winland, R.L. and Wolf, M. (1996) Schwertmannite and the Chemical Modeling of Iron in Acid Sulfate Waters. Geochimica et Cosmochimica Acta, 60, 2111-2121.

[14] Waychunas, G.A., Myneni, S.C.B., Traina, S.J., Bigham, J.M., Fuller, C.C. and Davis, J.A. (2001) Reanalysis of the Schwertmannite Structure and the Incorporation of SO42-Groups: An IR, XAS, WAXS and Simulation Study. Lawrence Berkeley National Laboratory.

[15] Webster, J.G., Swedlund, P.J. and Webster, K.S. (1998) Trace Metal Adsorption onto an Acid Mine Drainage Iron(III) Oxy Hydroxy Sulfate. Environmental Science and Technology, 32, 1361-1368. https://doi.org/10.1021/es9704390

[16] Liao, Y., Liang, J. and Zhou, L. (2011) Adsorptive Removal of As(III) by Biogenic Schwertmannite from Simulated As-Contaminated Groundwater. Chemosphere, 83, 295-301.

[17] Paikaray, S., Göttlicher, J. and Peiffer, S. (2011) Removal of As(III) from Acidic Waters Using Schwertmannite: Surface Speciation and Effect of Synthesis Pathway. Chemical Geology, 283, 134-142.

[18] Fukushi, K., Sasaki, M., Sato, T., Yanase, N., Amano, H. and Ikeda, H. (2003) A Natural Attenuation of Arsenic in Drainage from an Abandoned Arsenic Mine Dump. Applied Geochemistry, 18,1267-1278.

[19] Fukushi, K., Sato, T. and Yanase, N. (2003) Solid-Solution Reactions in As(V) Sorption by Schwertmannite. Environmental Science \& Technology, 37, 3581-3586. https://doi.org/10.1021/es026427i

[20] Vanderborght, B.M. and Van Grieken, R.E (1977) Enrichment of Trace Metals in Water by Adsorption on Acitivated Carbon. Analytical Chemistry, 49, 311-316. https://doi.org/10.1021/ac50010a032

[21] Fukushi, K., Sato, T., Yanase, N., Minato, J. and Yamada, H. (2004) Arsenate Sorption on Schwertmannite. American Mineralogist, 89, 1728-1734.

https://doi.org/10.2138/am-2004-11-1219

[22] Burton, E.D., Bush, R.T., Johnston, S.G., Watling, K.M., Hocking, R.K., Sullivan, L.A. and Parker, G.K. (2009) Sorption of Arsenic(V) and Arsenic(III) to Schwertmannite. Environmental Science \& Technology, 43, 9202-9207. https://doi.org/10.1021/es902461x

[23] Bethke, C.M. (2007) Geochemical and Biogeochemical Reaction Modeling. 2nd Edition, Cambridge University Press, Cambridge. https://doi.org/10.1017/CBO9780511619670

[24] Carlson, L., Bigham, J.M., Schwertmann, U., Kyek, A. and Wagner, F. (2002) Scavenging of As from Acid Mine Drainage by Schwertmannite and Ferrihydrite: A Comparison with Synthetic Analogues. Environmental Science \& Technology, 36, 1712-1719. https://doi.org/10.1021/es0110271

[25] Sverjensky, D.A. (1984) Prediction of Gibbs Free Energies of Calcite-Type Carbonates and the Equilibrium Distribution of Trace Elements between Carbonates and Aqueous Solutions. Geochimica et Cosmochimica Acta, 48, 1127-1134.

[26] Tesoriero, A.J. and Pankow, J.F. (1996) Solid Solution Partitioning of $\mathrm{Sr}^{2+}, \mathrm{Ba}^{2+}$, and 
$\mathrm{Cd}^{2+}$ to Calcite. Geochimica et Cosmochimica Acta, 60, 1053-1063.

[27] Rimstidt, J.D., Balog, A. and Webb, J. (1998) Distribution of Trace Elements between Carbonate Minerals and Aqueous Solutions. Geochimica et Cosmochimica Acta, 62, 1851-1863.

[28] Knorr, K.H. and Blodau, C. (2007) Controls on Schwertmannite Transformation Rates and Products. Applied Geochemistry, 22, 2006-2015.

[29] Dove, P.M. and Rimstidt, J.D. (1985) The Solubility and Stability of Scorodite, $\mathrm{FeAsO}_{4} \cdot 2 \mathrm{H}_{2} \mathrm{O}$. American Mineralogist, 70, 838-844.

[30] Yu, J.Y., Heo, B., Choi, I.K., Cho, J.P. and Chang, H.W. (1999) Apparent Solubilities of Schwertmannite and Ferrihydrite in Natural Stream Waters Polluted by Mine Drainage. Geochimica et Cosmochimica Acta, 63, 3407-3416.

[31] Busenberg, E. and Plummer, L.N. (1989) Thermodynamics of Magnesian Calcite Solid-Solutions at $25^{\circ} \mathrm{C}$ and 1 atm Total Pressure. Geochimica et Cosmochimica Acta, 53, 1189-1208.

[32] Glynn, P.D. and Reardon, E.J. (1990) Solid-Solution Aqueous-Solution Equilibria: Thermodynamic Theory and Representation. American Journal of Science, 290, 164- 201. https://doi.org/10.2475/ajs.290.2.164

[33] Plummer, N.L., Busenberg, E., Glynn, P.D. and Blum, A.E. (1992) Dissolution of Aragonite-Strontianite Soild Solutions in Nonstoichiometric $\mathrm{Sr}\left(\mathrm{HCO}_{3}\right)_{2}-\mathrm{Ca}\left(\mathrm{HCO}_{3}\right)_{2}-$ $\mathrm{CO}_{2}-\mathrm{H}_{2} \mathrm{O}$ Solutions. Geochimica et Cosmochimica Acta, 56, 3045-3072.

[34] Barham, R.J. (1997) Schwertmannite: A Unique Mineral, Contains a Replaceable Ligand, Transforms to Jarosites, Hematites, and/or Basic Iron Sulfate. Journal of Materials Research, 12, 2751-2758. https://doi.org/10.1557/JMR.1997.0366

Submit or recommend next manuscript to SCIRP and we will provide best service for you:

Accepting pre-submission inquiries through Email, Facebook, LinkedIn, Twitter, etc. A wide selection of journals (inclusive of 9 subjects, more than 200 journals)

Providing 24-hour high-quality service

User-friendly online submission system

Fair and swift peer-review system

Efficient typesetting and proofreading procedure

Display of the result of downloads and visits, as well as the number of cited articles

Maximum dissemination of your research work

Submit your manuscript at: http://papersubmission.scirp.org/

Or contact jmmce@scirp.org 